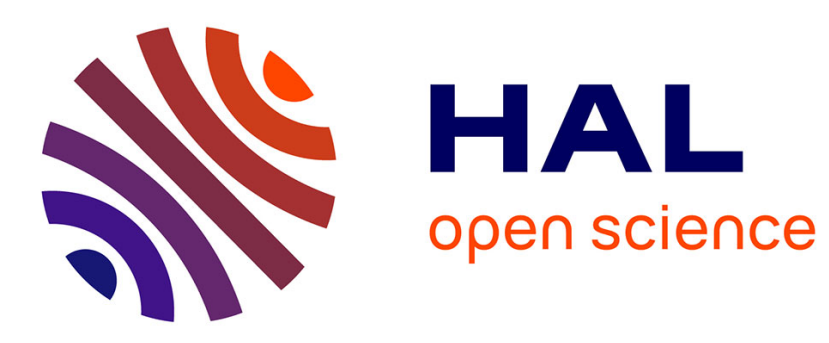

\title{
Complex Safety Study of intelligent multi-robot navigation in risk's environment
}

Chaima Bensaci, Youcef Zennir, Denis Pomorski, El-Arkam Mechhoud

\section{To cite this version:}

Chaima Bensaci, Youcef Zennir, Denis Pomorski, El-Arkam Mechhoud. Complex Safety Study of intelligent multi-robot navigation in risk's environment. The 51st International Carnahan Conference on Security Technology, Oct 2017, Madrid, Spain. 10.1109/CCST.2017.8167809 . hal-03508668

\section{HAL Id: hal-03508668 \\ https://hal.archives-ouvertes.fr/hal-03508668}

Submitted on 3 Jan 2022

HAL is a multi-disciplinary open access archive for the deposit and dissemination of scientific research documents, whether they are published or not. The documents may come from teaching and research institutions in France or abroad, or from public or private research centers.
L'archive ouverte pluridisciplinaire HAL, est destinée au dépôt et à la diffusion de documents scientifiques de niveau recherche, publiés ou non, émanant des établissements d'enseignement et de recherche français ou étrangers, des laboratoires publics ou privés. 


\section{Complex Safety Study of intelligent multi-robot navigation in risk's environment}

\author{
Chaima BENSACI \\ Université 20 Août 1955 Skikda \\ LGCES Laboratory \\ Skikda, Algeria \\ ch.bensaci@univ-skikda.dz
}

\author{
Youcef ZENNIR \\ Université 20 Août 1955 Skikda \\ Automatic Laboratory of Skikda \\ Skikda, Algeria \\ y.zennir@univ-skikda.dz
}

\author{
Denis POMORSKI \\ Université Lille 1 \\ CRIStAL Laboratory-UMR 9189 \\ Lille, France \\ denis.pomorski@univ-lille1.fr
}

\author{
El-Arkam MECHHOUD \\ Université 20 Août 1955 Skikda \\ Automatic Laboratory of Skikda \\ Skikda, Algeria \\ e.mechhoud@univ-skikda.dz
}

\begin{abstract}
The issue investigated in this paper concerns navigation, survey / control and the complexity associated with a mobile multi-robot coordination and cooperation in a complex environment (robotic analysis laboratory), which is little or no known with significant industrial risks, in the presence of human and machines. This group of mobile robots is mainly used to move chemicals products, which can lead dangerous accidents (toxic, flammable, explosive ...) between the different rooms of the laboratory. The objective of our study is to ensure a good precision in the robots navigation in order to optimize human efforts, reduced error and establishment safety while keeping an eye on robots with good functioning and a desired production. In the literature there are several risk analysis techniques. Among the most used techniques in robotics, the FMEA method (failure modes, effects and criticality analysis). We applied the method FMEA on one robot. Then, the method FTA was chosen to generalize dependability study on all robots. Finally, To manage this level of complexity, a control architecture based on controllers decomposition into a set of elementary behaviors / controllers (obstacles avoidance and collision between robots, attraction to a target, planning ...) was proposed.
\end{abstract}

Keywords- FMEA, Multi-mobile robots system, Navigation control/command, Risks analysis, Safety level, Simulator.

\section{INTRODUCTION}

The human being ambition to make his life easier, and his inability to carry out different missions because of their difficulties or their influence on his health, urge them to discover and develop solutions to achieve this objective, mobile robotics is one of these solutions. With the technological development, mobile robotics invaded a variety of fields. Among these areas of possible application especially that requires research include robotics dedicated to hazardous environments where safety is a major step.

The test platform of our work is a robotic chemical analysis laboratory equipped with analysis machines; various risk products where the human being is present. Navigating safely these multi-robots under these conditions presents a great challenge. For a robots group capable of cooperate and navigate accurately and safely without accidents, the focus at first was on risk scenarios that could be considered, then a possible risk analysis was made in order to achieve better multi-robots surveying / (controlling) commanding .

\section{DESCRIPTION OF RISKS SCENARIOS}

A robotic chemical analysis laboratory is the dynamic simulation platform used in this work. A miniature model of the laboratory consists of two rooms was developed under VRep simulator. The laboratory contains robots and human beings collaborating together to perform complex risk tasks, these robots transport chemical products that are harmful to human health and to the environment (toxic, flammable, explosive) within the room as shown in the follows figure.

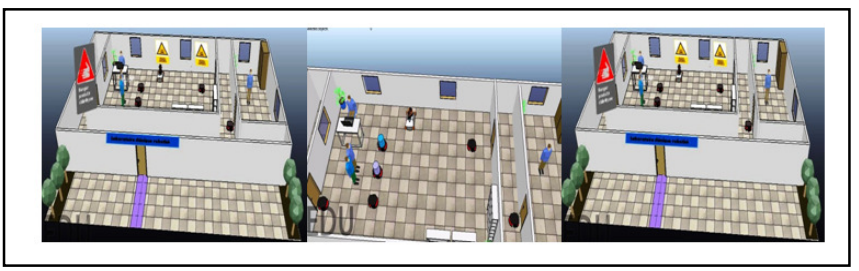

Fig. 1. Scenario of a robots in normal operation within a laboratory room Exposed to various risks.

Thus, these robots can move between the different laboratory rooms. The figure (2) shows a robot moving to the other rooms.

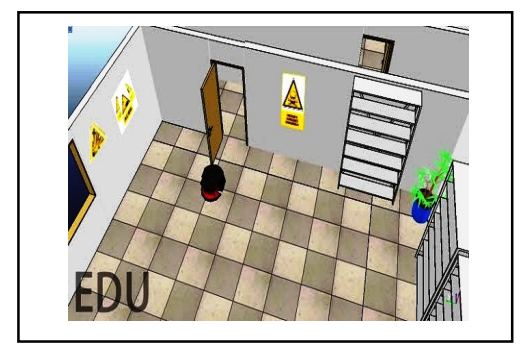

Fig. 2. Scenario represents a robot moving between different laboratory rooms where hazards exist.

During robots collaboration to perform the task requested, accidents are likely to generate between robots also between a failing robot and a human being stemming from the problems of communication, interaction and organization. The following figures present possible accident scenarios. 


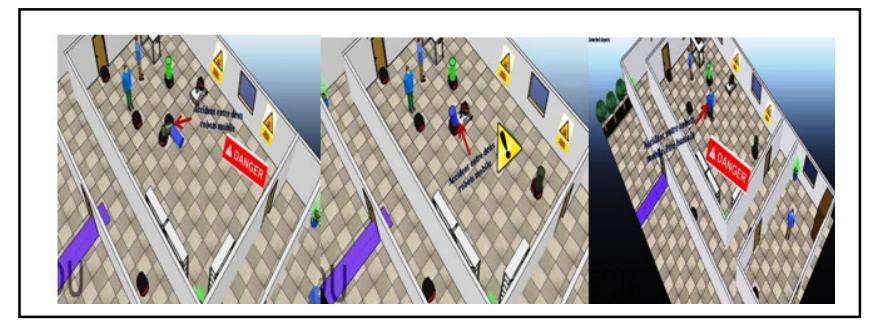

Fig. 3. Scenario represents a robot moving between different laboratory rooms where hazards exist.

Potential accidents can be broken down as follows:

1. Collision of empty robots with high speed;

2. Collision between a robot loaded with chemical products and empty robots and between robot and human being;

3. Collision of robots loaded with chemical products;

4. A robot fails when it is moving dangerous products, its main task is the transport of these products in a precise time.

The table below classifies the various possible accidents from the severity of its consequences.

TABLE I. Classification of possible accidents and its consequences

\begin{tabular}{|c|c|c|c|}
\hline \multicolumn{2}{|c|}{ Possible accidents } & $\begin{array}{c}\text { Consequences } \\
\text { of accidents }\end{array}$ & Criticality \\
\hline \multicolumn{2}{|r|}{ Case 1} & $\begin{array}{c}\text { Robots } \\
\text { degradation }\end{array}$ & $\mathrm{C}_{0}$ \\
\hline \multirow{3}{*}{$\begin{array}{c}\text { Case } \\
2\end{array}$} & $\begin{array}{l}\text { Robot loaded with } \\
\text { explosive product }\end{array}$ & $\begin{array}{c}\text { Risk of } \\
\text { explosion }\end{array}$ & \multirow[t]{3}{*}{$\mathrm{C}_{2}$} \\
\hline & $\begin{array}{l}\text { Robot loaded with } \\
\text { Extremely or easily } \\
\text { flammable product }\end{array}$ & Risk of fire & \\
\hline & $\begin{array}{l}\text { Robot loaded with } \\
\text { very toxic or toxic gas }\end{array}$ & $\begin{array}{l}\text { Risk of toxicity } \\
\text { and asphyxia }\end{array}$ & \\
\hline $\begin{array}{c}\text { Case } \\
3\end{array}$ & $\begin{array}{l}\text { Robots Loaded with } \\
\text { explosives ; } \\
\text { flammables products } \\
\text { toxic gas or } \\
\text { incompatible products }\end{array}$ & $\begin{array}{c}\text { Risk of } \\
\text { explosion; fire; } \\
\text { toxicity and } \\
\text { asphyxia; dust; } \\
\text { Flammable } \\
\text { vapors or gases }\end{array}$ & $\mathrm{C}_{3}$ \\
\hline \multirow[t]{4}{*}{$\begin{array}{c}\text { Case } \\
4\end{array}$} & $\begin{array}{l}\text { Robot loaded with } \\
\text { explosive product }\end{array}$ & $\begin{array}{l}\text { Risk of } \\
\text { explosion, } \\
\text { fatality }\end{array}$ & \multirow[t]{4}{*}{$\mathrm{C}_{4}$} \\
\hline & $\begin{array}{l}\text { Robot loaded with } \\
\text { Extremely or easily } \\
\text { flammable product }\end{array}$ & $\begin{array}{l}\text { Risk of fire, } \\
\text { human burn }\end{array}$ & \\
\hline & $\begin{array}{l}\text { Robot loaded with } \\
\text { very toxic or toxic gas }\end{array}$ & $\begin{array}{c}\text { Risk of human } \\
\text { toxicity and } \\
\text { asphyxia } \\
\end{array}$ & \\
\hline & $\begin{array}{l}\text { Robot loaded with } \\
\text { Corrosive and } \\
\text { irritating products }\end{array}$ & $\begin{array}{c}\text { Destruction of } \\
\text { human skin or } \\
\text { eye tissue }\end{array}$ & \\
\hline & Case 5 & $\begin{array}{l}\text { Change of } \\
\text { chemical } \\
\text { product } \\
\text { properties }\end{array}$ & $\mathrm{C}_{1}$ \\
\hline
\end{tabular}

\section{DESCRIPTION OF THE ROBOT USED TURTLEBOT 2}

TurtleBot 2 is a robot compatible with ROS. It consists of a Kobuki robot, a Kinect, a Laptop and trays for the installation of these two components. The TurtleBot 2 comes from the Canadian company ClearPath but the Kobuki is manufactured by Yujin in Korea and the Kinect by Microsoft in the United States. The Kobuki base is inspired by robot vacuums; it is a robot with two differential wheels with proximity sensors, encoders on the wheels and a gyrometer for each axis [1].

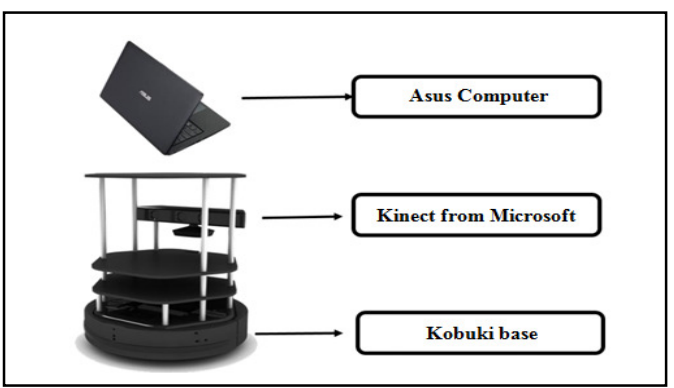

Fig. 4. TurtleBot 2 components [1].

\section{A. The computer of the robot}

The computer attached to the TurtleBot is an ASUS eeePC which is a lightweight netbook. The main task of the robot computer is to receive data and send it to a desktop computer or save it to a hard drive. The robot computer also interacts with the TurtleBot hardware. Because of the computing power in the robot computer, some calculations can also advantageously be performed on this computer, instead of letting the computer desktop do all the work [1].

\section{B. The Kinect}

Originally, The Kinect is a device for the Xbox 360 console to control video games without using a joystick. It was designed by Microsoft in September 2008 [4].

1) The components of a Kinect: The following figure shows the various components of the kinect.

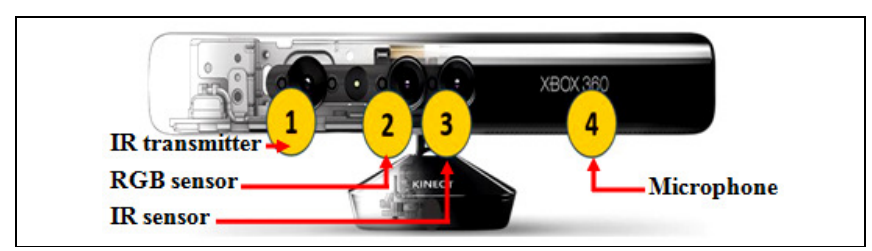

Fig. 5. The components of a Kinect XBOX360 [1].

a) An infrared emitter (IR) and an IR depth sensor:

The transmitter emits beams of infrared light and the depth sensor reads the reflected infrared beams towards the sensor. The reflected beams are converted into depth information measuring the distance between an object and the sensor. This makes capturing a depth image possible.

b) An RGB camera that stores data from three channels has a resolution of $1280 \times 960$. This makes capturing a color image possible. 
c) Microphone Row, which contains four microphones to capture the sound. Because there are four microphones, it is possible to record audio as well as find the location of the sound source and the direction of the sound wave.

d) A 3-axis accelerometer configured for a $2 g$ range, where $\mathrm{g}$ is acceleration due to gravity. It is possible to use the accelerometer to determine the current orientation of the Kinect [1]

\section{The Kobuki base}

The mobile robot Kobuki is the mobile base of the TurtleBot 2. The robot iClebo Kobuki of Yujin Robot is a mobile development platform for education, research and for all those who want to develop their high-level applications. It is equipped with:

a) Encoders: The encoder is a sensor attached to a rotating object to measure rotation. By measuring the rotation we can determine the displacement, speed, acceleration of the robot.

b) Bumpers: There are 3 bumpers distributed between the left, the center and the right sides of the base.

c) Vacuum sensors: Likewise, 3 sensors are distributed between the left, the center and the right part of the base.

d) Wheel descent sensors: There are 2 of these sensors one for each wheel (left, right).

e) Gyroscope: It is a sensor of angular speeds on 3 axes $\mathrm{x}, \mathrm{y}$ and $\mathrm{z}$.

f) Dashboard: This is an interface tool provided by ROS that allows us to check the states of the sensors and different equipment such as the state of charge of the batteries (laptop + TurtleBot) [1].

\section{METHODS USED}

The aim of this study is to ensure maximum accuracy in the navigation of robots also the dependability in working environment in order to optimize the human safety [5], establishments and to preserve the proper functioning of these agents (robots). To achieve this goal, we first need to ensure microscopic safety, to solve the navigation and control problems of each mobile robot so as to ensure macroscopic safety at the laboratory level, to take into account the interactions between the various agents to preserve the entire environment from the occurrence of accidents.

The following figures present the safety theory followed. Where: Microscopic safety means the dependability of each robot while macroscopic safety include the dependability of the whole laboratory.

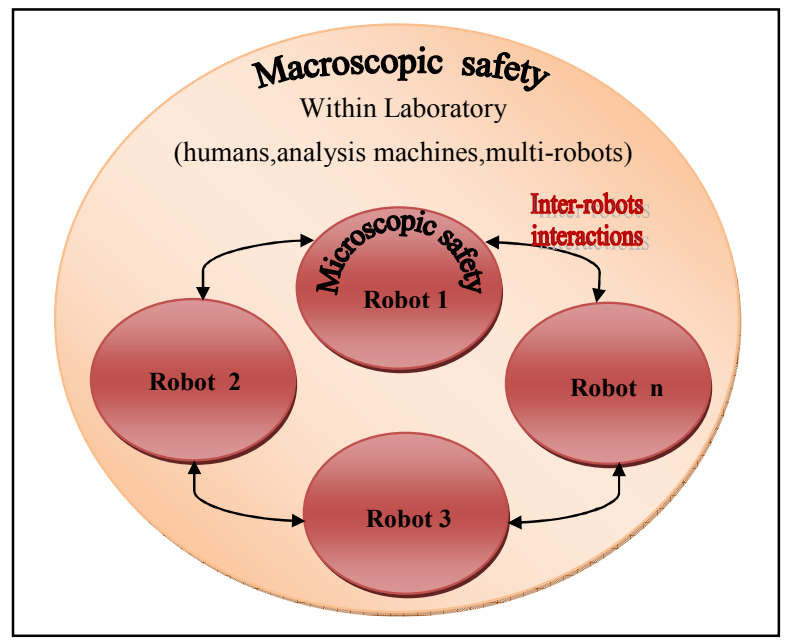

Fig. 6. Schema of the safety theory followed.

Dependability part is based on two methods of different approach, one of an inductive approach and the other of a deductive approach [5]. First, we applied the FMEA method (Failure Mode and Effects Analysis Method) on one robot.Then,we complet this part by using the FTA method (Fault Tree Analysis) to analyze the multi-robot communication risks . Concerning the control / command part a behavioral approach has been adopted. This approach makes it possible to distribute the control over the robotic entities by decomposing the global task into a set of elementary tasks. the control architecture then has a set of behaviors / controllers. Each one can accomplish a corresponding elementary task (avoidance of obstacles and collision between robots, attraction to a target, planning, etc.)[2]. The following diagram summarizes the methods used in this paper as well as the relationship between dependability and intelligent control.

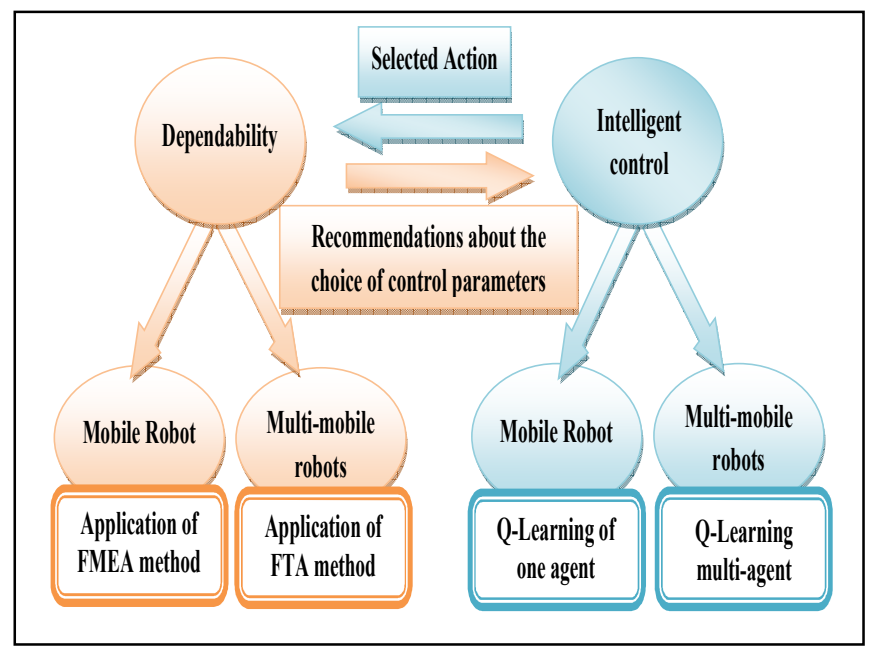

Fig. 7. Diagram summarizing the methods used and the relation between intelligent control and dependability.

The specificity of the theoretical approach consists in combining the advantages of multi-controller architectures 
with those of multi-agent systems, artificial intelligence and organizational models in order to bring a high level of mobile robots is coordinated according to the different standards and specifications of the organizational model. Thus, the activation of an elementary behavior in favor of another is done by respecting the structural constraints of the robots in order to ensure the maximum precision and security of the coordinated movements between the different mobile entities (robots). Different cooperation strategies can be considered as examples:

- Cooperation carried out through a centralized supervisor so that the desired destination can be reached more quickly, unexpected events are managed individually by the mobile agents / robots in a distributed way.

- Cooperation with reinforcement learning [6].

- Cooperation with a selfish or collaborative aspect.

\section{APPLICATION AND RESULTS}

\section{A. Dependability part}

\section{1) Application of FMEA method:}

Table II below shows the application of the FMEA method on a Turtelbot 2 robot. coordination between the mobile agents / robots. The group of

\section{2) Application of FTA method:}

Figure 9 presents the FTA method applied over the entire laboratory environment, we have chosen collision of robot as a top event, this collision leads to the occurrence of serious industrial risks: explosion, fire, chemical spills, Hazardous waste (toxic gas, dust, smoke, etc.)....For exemple the risk of explosion can appear if one of these three cases happened (figure 8):

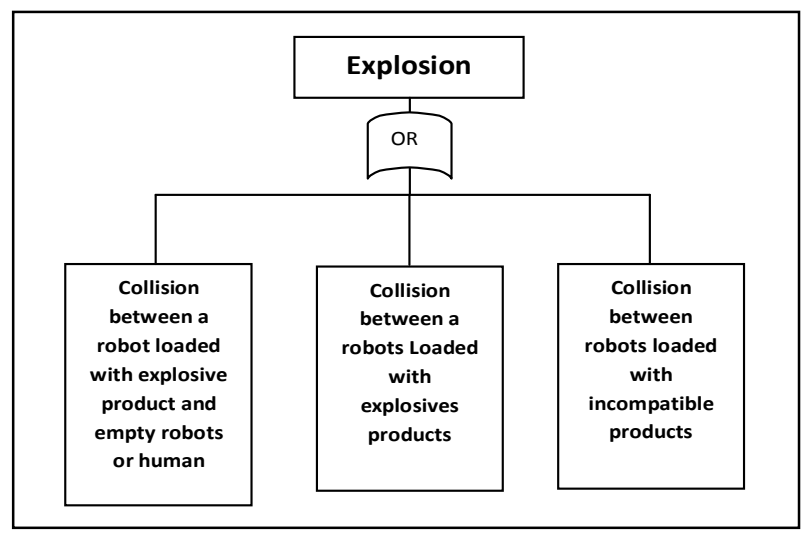

Fig. 8. Schema represents causes that can lead to an explosion.

\begin{tabular}{|c|c|c|c|c|c|c|}
\hline Component & Function & Failure Mode & Cause & Effect & Detection & Action \\
\hline $\begin{array}{l}\text { Visual sensor } \\
\text { (RGB Camera) }\end{array}$ & $\begin{array}{l}\text { Visual detection and } \\
\text { obstacle tracking } \\
\text { (object scanning and } \\
\text { color detection). }\end{array}$ & $\begin{array}{l}\text { - Bad image quality. } \\
\text { - Incomplete Image. }\end{array}$ & $\begin{array}{l}\text { - Low luminosity. } \\
\text { - Failure of the motor } \\
\text { responsible for moving the } \\
\text { sensor. }\end{array}$ & $\begin{array}{l}\text { - Bad detection of static } \\
\text { and dynamic obstacles. }\end{array}$ & $\begin{array}{l}\text { - IR Sensor. } \\
\text { - Dashboard } \\
\text { Kobuki. }\end{array}$ & $\begin{array}{l}\text { - It is necessary to make } \\
\text { periodic tests especially } \\
\text { with each sensors } \\
\text { initialization. }\end{array}$ \\
\hline \multirow[t]{3}{*}{$\begin{array}{l}\text { Infrared Depth } \\
\text { Sensor } \\
\text { ( IR Sensor) }\end{array}$} & \multirow{3}{*}{$\begin{array}{l}\text { Measures distance } \\
\text { between obstacle or } \\
\text { object and sensor } \\
\text { (detects depth) }\end{array}$} & $\begin{array}{l}\text { - No sensor indication } \\
\text { (null value). }\end{array}$ & $\begin{array}{l}\text { - Internal sensor failure or } \\
\text { connection. } \\
\text { - IR Transmitter Failure. }\end{array}$ & $\begin{array}{l}\text { - False command. } \\
\text { - There is No Motion or } \\
\text { undesired movement. }\end{array}$ & $\begin{array}{l}\text { Dashboard } \\
\text { Kobuki. }\end{array}$ & $\begin{array}{l}\text { - Testing sensors and } \\
\text { transmitters during } \\
\text { initialization. }\end{array}$ \\
\hline & & $\begin{array}{l}\text { - False sensor } \\
\text { indication (Random or } \\
\text { constant values). }\end{array}$ & - Inadequate calibration. & $\begin{array}{l}\text { - Error calculating the } \\
\text { coordinates of objects on } \\
\text { particular points. } \\
\text { - Risk of collision with } \\
\text { human beings or with the } \\
\text { other robots (Human and } \\
\text { material damage). }\end{array}$ & & $\begin{array}{l}\text { - Check the sensor } \\
\text { calibration. }\end{array}$ \\
\hline & & $\begin{array}{l}\text { - Aberrant values or a } \\
\text { deviation in the point } \\
\text { cloud resulting. }\end{array}$ & $\begin{array}{l}\text { - Strong lighting. } \\
\text { - Properties of the object } \\
\text { surface (shiny surfaces). }\end{array}$ & $\begin{array}{l}\text { - Appearance of laser } \\
\text { speckles with low } \\
\text { contrast in the infrared } \\
\text { image. }\end{array}$ & & $\begin{array}{l}\text { - Consider setting the } \\
\text { laboratory lighting. }\end{array}$ \\
\hline $\begin{array}{c}\text { Voice recognition } \\
\text { Sensor } \\
\text { (microphone) }\end{array}$ & $\begin{array}{l}\text { - Capture sound } \\
\text { - Record audio } \\
\text { - Find the location of } \\
\text { the sound source and } \\
\text { the direction of the } \\
\text { sound wave. }\end{array}$ & $\begin{array}{l}\text { - No or wrong sensor } \\
\text { indication. }\end{array}$ & $\begin{array}{l}\text { - Sensor internal failure. } \\
\text { - Noise. }\end{array}$ & $\begin{array}{l}\text { - The sensor can not } \\
\text { detect the source and the } \\
\text { sound direction which } \\
\text { may arise from } \\
\text { navigation errors. } \\
\text { - False command. }\end{array}$ & $\begin{array}{l}\text { - Dashboard } \\
\text { Kobuki. } \\
\text { - IR Sensor. } \\
\text { - RGB Camera. }\end{array}$ & \\
\hline Robot Controller & $\begin{array}{l}\text { Control the robot by } \\
\text { issuing commands. }\end{array}$ & $\begin{array}{l}\text { - Blocked or frozen } \\
\text { (constant command) }\end{array}$ & $\begin{array}{l}\text { - Blocking the program or } \\
\text { the operating system. }\end{array}$ & $\begin{array}{l}\text { - Sends constant } \\
\text { commands. } \\
\text { - Movement blocked at } \\
\text { one point (frozen robot). }\end{array}$ & & $\begin{array}{l}\text { - Reset and User Alert. } \\
\text { - Prevention techniques } \\
\text { for software } \\
\text { development. }\end{array}$ \\
\hline
\end{tabular}




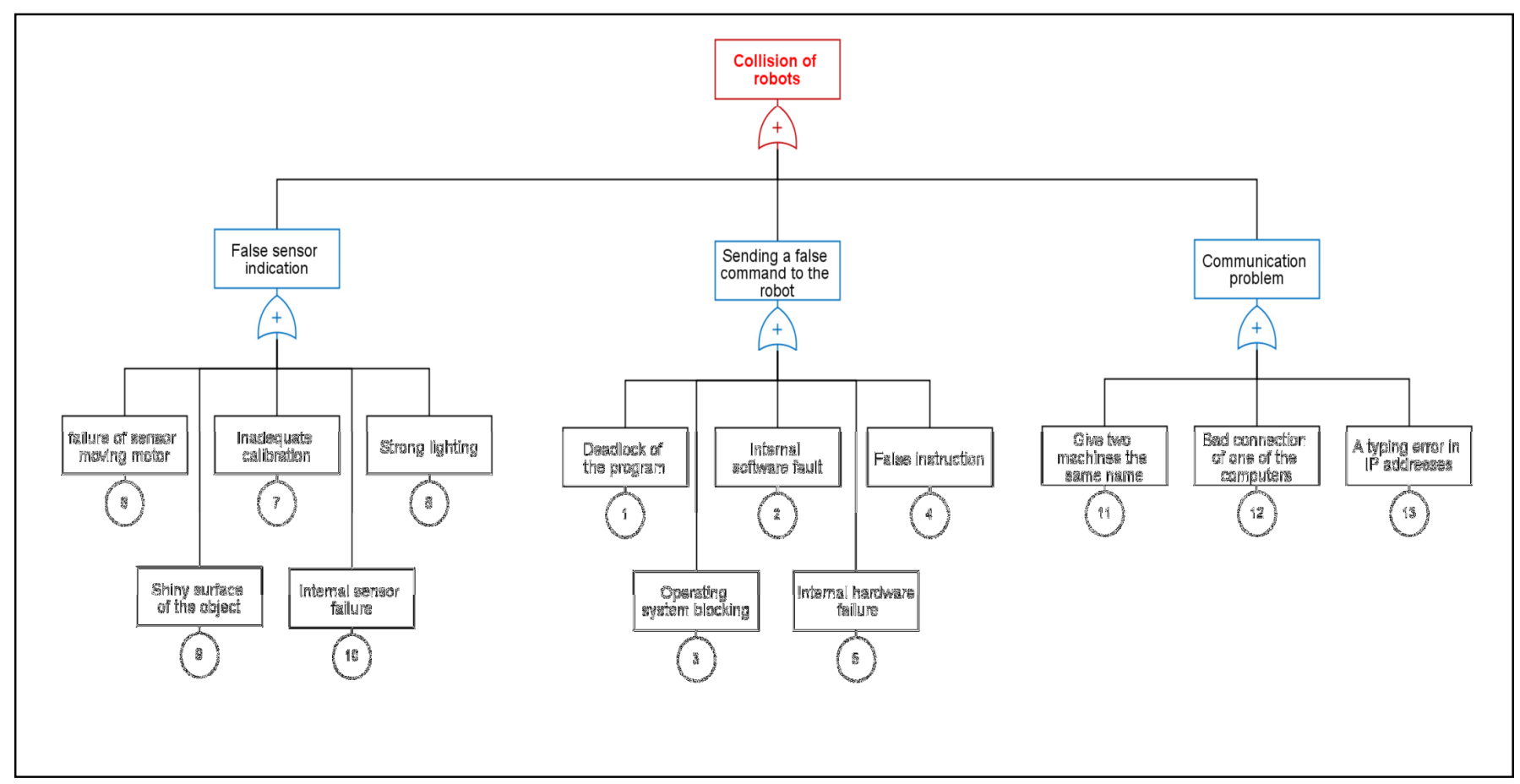

Fig. 9. Application of FTA method

Results obtained :

After the application of FMEA method on a robot; the recommendations that were obtained to ensure its proper functioning and minimize its risks are as follows:

- It is necessary to make periodic tests especially at each initialization of the various components (sensors, actuators ...);

- $\quad$ The setting up of prevention and protection means against risks such as prohibition signs and fire extinguishers within the laboratory;

- The use of fault prevention techniques for developed software;

- Emergency shutdown by the operator in case of serious malfunction;

- An alert that will indicate the existence or not of an internal robot default;

- A sensor must be added indicating the battery status.

According to the FTA method the fault tree which can lead to a collision of robots depend to a three major problems:

- False sensor indication;

- Sending a false command to the robot;

- Communication problems.

\section{B. Intelligent control part}

In the literature there are different navigation control approaches of a mobile robot where multi-robots in an unknown environment [7-9]. The approach proposed for controlling robot navigation in an unknown or partially unknown environment with the presence of obstacles is multi-agent systems approach and reinforcement learning [10]. The architecture control of a single robot is illustrated in the following figure:

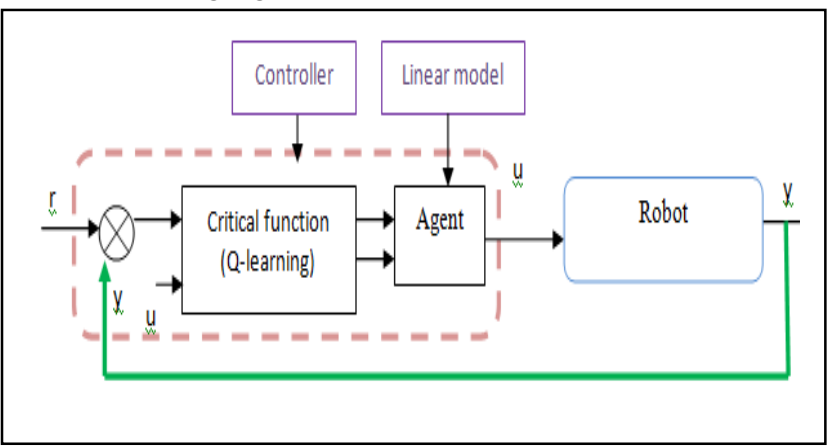

Fig.10. Synoptic of the control architecture to be applied (case one robot (agent)).

We take note that:

- Agent: It is the linear model around an operating point.

- State's': It is a continuous state space.

- Action 'a': It is the local command around an operating point.

- The operation point is the points of equilibrium of the system which may be stable or not.

- The critical function: the set of criteria to reward or not the chosen command. 
Among the existing methods in the reinforcement learning approach, we have chosen to use the Q-learning and Qlearning-multi-agent algorithms [11-15] in the case of multirobots.

We are faced with a learning of a dynamic system which implies a space of state and continuous action. Following the learning a command will be sent to the nonlinear process (TurtleBot 2 mobile robot). The architecture control in the multi-agents case is represented by the following figure:

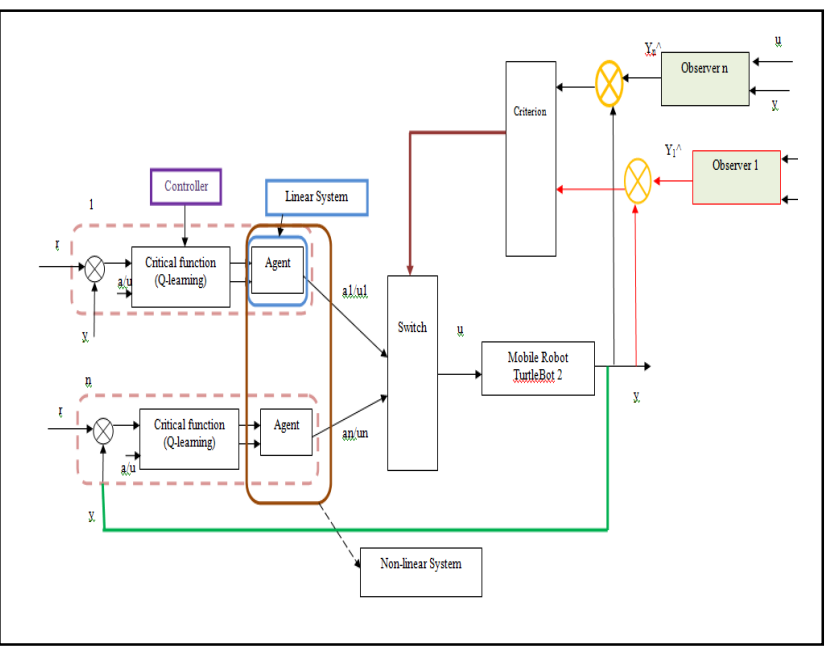

Fig. 11. Synoptic of the multi-agents control architecture.

The different signal are :

- The state of the system is known in a global or partial way from the various sensors, GPS and others.

- The optimization criterion of the error: there are several criteria, for example the quadratic error.

- The reinforcement signal: there are several methods to calculate or determinate this reinforcement signal, they still have to be adapted to our problem.

The interaction between agents is done through the environment, in such a way that an agent takes into account the actions of other agents in order to make the right decision (action).

\section{CONCLUSION}

In this paper we have tried to develop a risk analysis using the FMEA method on a TurtelBot 2 robot and the FTA method for the multi-robot. So we use two main concepts which are macroscopic and microscopic safety. Next, we proposed control architecture with a set of elementary behaviors / controllers in order to ensure the maximum accuracy and safety of the coordinated movements between the different mobile entities. Microscopic safety is the dependability of each robot. As for the macroscopic safety means the dependability of the overall of laboratory. To minimize the major risks in the laboratory we must increase the safety level integrated. In order to ensure the proper functioning of the robots and Increase the level of safety in the laboratory recommendations have been obtained. In the future work we applied the architecture control for one robot and multi-robots (11 robots) In order to improve the control and safety of the system and compared with nether approach of control (Q-fuzzy-muli-agent algorithm for example).

\section{REFERENCES}

[1] F.WEHBI, "Architecture logicielle et matérielle pour fusion tolérantes au fautes pour systèmes multi-robots sous ROS“. Raport, Lille and Libanon University,2015, p.64.

[2] M. Mouad, "Architecture de Contrôle/Commande dédiée aux systèmes Distribués Autonomes : application à une plate-forme multivéhicules". Phd these, Blaise Pascal - Clermont-Ferrand II University, 2014, p. 217.

[3] J. Guiochetg, "Maîtrise de la sécurité des systèmes de La robotique de service Approche UML basée sur une Analyse du risque système", Phd these, INSA-Toulouse, 2003, p.212

[4] Bertrand PECUCHET, KINECT for X BOX 360, Université Lille 1, 17 pages, 2012-2013.

[5] L.Froquet, “Contribution à l'analyse des risques : Proposition d'une méthode par scénarios et capitalisation de la connaissance“, Phd these, Institut National Polytechnique de Grenoble - INPG, 2005, p.126.

[6] Y. Zennir and D. Pomorski, "Multi-Actors distributed control systems: Reinforcement signal by Shannon's Entropy“, The 24th European modeling \& simulation on symposium (EMSS'12), Vienna, Austria, 19-21 September, 2012 , pp.103-108. ISBN 978-88-9799909-6.

[7] S. Dutta, "Obstacle Avoidance of mobile robot using PSO based Neuro Fuzzy Technique", International Journal on Computer Science and Engineering (IJCSE'10), Vol. 02, No. 02, 2010, pp.301-304

[8] Y. Zennir and P. Couturier, "Control of the trajectory of a hexapod robot based on distributed Q-learning. IEEE International Symposium on Industrial Electronics, Ajaccio, France,2004, pp.277-282.

[9] Y. Zennir, P. Couturier and M. Bétemps, "Distributed reinforcement learning of a six-legged robot to walk". 4th International conference on control and automation, IEEE Control chapter, Singapore, Montreal section, Montréal, Canada, 2003, pp. 896-900.

[10] Md. Rakibul Islam, Md. Tajmiruzzaman, Md. Mahfuzul Haque Muftee, Md. Sanowar Hossain," Autonomous Robot Path Planning Using Particle Swarm Optimization in Dynamic Environment with Mobile Obstacles \& Multiple Target”, International Conference on Mechanical, Industrial and Energy Engineering, 25-26 December, Khulna, BANGLADESH, 2014, pp.6.

[11] A.V. Gavrilov, A. Lenskiy, "Mobile Robot Navigation using Reinforcement Learning based on Neural Network with Short Term Memory", International Conference on Intelligent Computing (ICIC '11), Zhengzhou, China, 2011,p.8

[12] C. Xia, "Intelligent Mobile Robot Learning in Autonomous Navigation", PhD these, École central de Lille, 2015, p.174

[13] Y. Zennir, A. Ben Ahmed and El-A. Mechhoud, "Safety study of the industrial system with $\operatorname{FMEA}(\mathrm{C})$ : Applied on the storage tank TK102“. International Europien Conference Control, ECC'14, june 24-27, Strasbourg, France, 2014, pp. 2804 - 2809.

[14] N. Altuntas, E. Imal, N. Emanet, C. Özturk, "Reinforcement learningbased mobile robot navigation“", Turk J Elec Eng \& Comp Sci, Vol. 24, p.1747-1767

[15] L. Khriji, F. Touati, K. Benhmed and A. Al-Yahmedi, "Mobile robot Navigation Based on Q-Learning Technique“, International Journal of Advanced Robotic Systems, Vol. 8, No. 1 (2011), ISSN 1729-8806, pp 45-51. 